\title{
Political Encampment and the Architecture of Public Space: TEKEL Resistance in Ankara
}

\begin{abstract}
The protest encampment established by the workers of TEKEL (meaning 'monopoly' in Turkish), the privatized former state enterprise that had held a monopoly on the production of tobacco and alcoholic beverages since 1925, stood in downtown Ankara for two and a half months despite the harsh winter conditions of 2010. The encampment created significant political impetus although it was ultimately not successful in obtaining its goals. Nevertheless, the camp was significant in terms of the spatial formation of public space. Pursuant to the global wave of protests in 2011, apart from being a response to the deprivation created by neo-liberalism, the TEKEL resistance also generated a particular form of urban spatial encampment. This article discusses the formation of the TEKEL encampment and the applicable embodied practices that emerged from it. The TEKEL encampment is dealt with in two ways. On the one hand, it is investigated amidst the processes of appropriation of public urban space. On the other hand, it is explored through the lens of the TEKEL workers' nomadic living conditions, dictated to them by the neo-liberal employment regime.
\end{abstract}

On December 17, 2009, workers who had arrived from different provinces began to gather in front of the headquarters of Türk-İs, the largest union confederation in Turkey located in downtown Ankara. This was not a planned event but a spontaneous gathering. The protestors were employed in TEKEL, the privatized former state enterprise that produced tobacco and alcoholic beverages. The previous two days had witnessed a dispersed series of protests

\section{Keywords}

political encampment protest camp

TEKEL

politics of public space Sakarya District

Ankara

nomadic architecture 
in various locations in the city, including Abdi İpekçi Park in the city centre and the headquarters of the Justice and Development Party (Adalet ve Kalkınma Partisi, AKP) in power, which is located five kilometres outside the centre. Since the police did not allow for the unification of different factions, small groups of workers and the police force dispersing them clashed frequently in different parts of the city during these two days. The government was determined to prevent a mass rally; hence the measures rapidly grew harsher. Finally, both the crowd in front of the AKP headquarters and those gathered in Abdi İpekçi Park were evacuated by force. It was immediately following the evacuation of the park that the scattered workers wandering in the streets filled with tear gas began to arrive at Türk-İş just a few blocks away. This spontaneous re-gathering would ignite the most significant political protest of recent years in Turkey. Soon, the workers would begin building tents that would rapidly turn into an encampment and stand for more than two months in spite of the harsh winter conditions [Figure 1].

The resistance tents of the workers quickly became a symbol of class politics and formed an alternative to the fruitless conflict between secularism and Islamism that has dominated the political sphere in Turkey since the late 1990s. The encampment attracted a significant number of solidarity visitors as well as left-wing activists who lived in the encampment and supported the logistics of daily life. Aside from the political impetus it created, the TEKEL resistance was also significant in terms of the spatial forms of political protest in Turkey. Although mass rallies in major cities (especially Istanbul and Ankara) - drawing also on participation from other cities - have been common, the encampment that stood in the city centre for two and a half months introduced a new form of public space. If we remember Hannah Arendt's insistence that the public space (of appearance) 'does not always exist' but is reconstructed each time with the social agents' participation in it, it becomes clear that the form of 'nomadic' dwelling introduced by the encampment produces a new form of public space. ${ }^{2}$

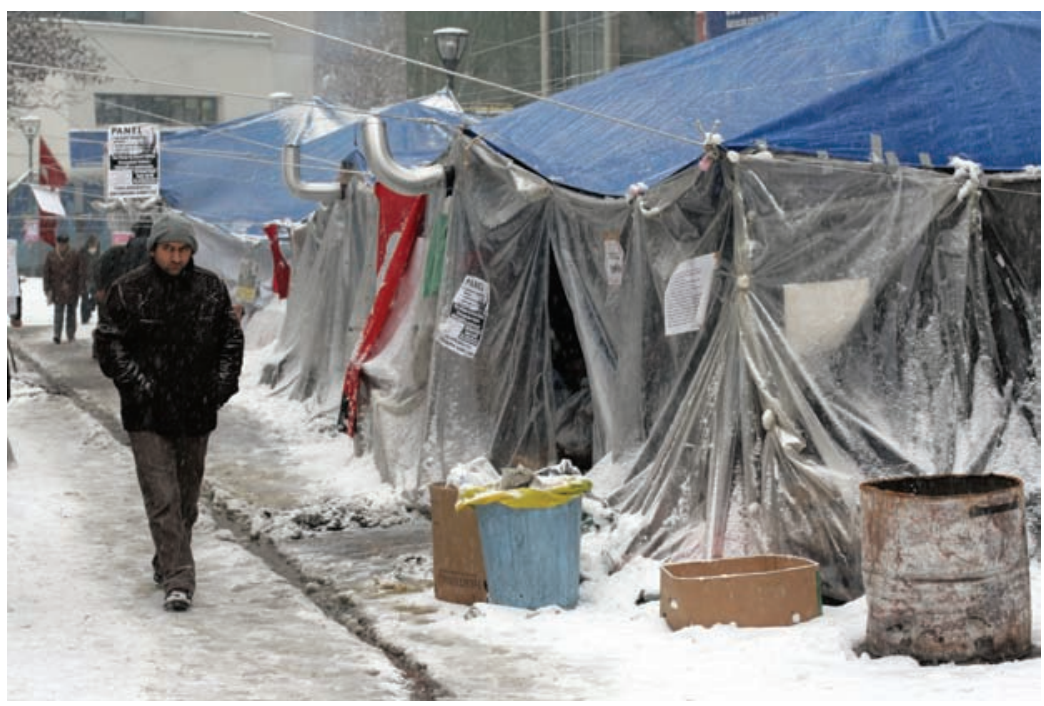

Mehmet Özer.

Figure 1: The tents of the TEKEL encampment. 
Protest camps have been erected in different parts of the world in response to various political developments especially in the second half of the twentieth century. Yet, the political encampment located in the city centre has become the trademark of the global tide of protest that has become effective since late 2010. From the 'Democracy Village' in London's Parliament Square to the tents in Cairo's Tahrir Square; from the Indignants' encampment in Puerte del Sol in Madrid to those in Zuccotti Park in New York City, protests globally have been realized through similar spatial forms. Although there are affinities between the TEKEL encampment in Ankara and this global trend, it is crucial to note that there are a number of peculiarities that separate the TEKEL protest from those that followed. First of all, in contrast to the heterogeneous character of the current wave of protests in terms of their demands and participant profiles, the TEKEL protest was a rather homogeneous working-class action pursued via the organizational body of a trade union (Tekgida-İs). Secondly, although it was seen as a spark that would start a new era in terms of popular movements (as are the global protests), it was not successful in achieving its goals. Despite its significance as an event, the TEKEL resistance proved to be an indicator of the fading power of the unions and the organized power of the working class in Turkey. These aspects differentiate the case of TEKEL resistance from the global tide of protests especially in terms of political contents as well as the organizational forms.

Although the TEKEL resistance precedes the protest camps of 2011, it shares with them the crucial common features of being a response to systemic deprivation created by neo-liberalism. ${ }^{3}$ Moreover, this commonality also extends to the particular architectural form of the encampment, albeit with certain distinctions that I will address below. In this article, I will analyse the TEKEL resistance in terms of the rearticulation of public space through spatial practices of political protest. My analyses are mainly based on personal observations of the encampment site, although I have also made use of studies conducted by various researchers. The political encampment is a particular architectural form that gives shape to the political appropriation of public space. Yet, in places where state power limits the effective use of public space, as in the case of Turkey, the protest camp can be utilized not only to occupy public space but also to reconstruct it within the urban fabric. I relate the architectural form of the protest camp to the meaning of dwelling in the age of neo-liberalism. I argue that the camp is an expression of the nomadic living conditions dictated to the workers by the neo-liberal employment regime forcing them to move between jobs. In this regard, the encampment can also be seen as a spatial response to the workers' social existence in Turkey as they are being relocated within the standardized apartment blocks constructed in recent years by the Mass Housing Administration (Toplu Konut İdaresi, TOKI). Finally, a general discussion of protest encampments facilitates a better understanding of the TEKEL resistance, the urban context within which it emerged, as well as the spatial experience of the encampment itself.

\section{The Protest Encampment}

Protest encampments have been constructed in different parts of the world since the second half of the twentieth century. ${ }^{4}$ They have functioned as events to expand the influence of rallies and demonstrations by stretching their existence in space and time. Since the mass rally interrupts the everyday life that normally takes place in its location, its power stems from the temporary shock 
it creates. The encampment, in contrast, builds on its ambiguous character fluctuating between temporariness and permanence. The protest camp can last for a very long time, yet it is always ready to be dismantled. Moreover, its ambiguity is also inscribed in its spatial form: the campsite simultaneously contains an exterior and an interior. It is, quite obviously, located outside; the camp by definition implies an open space activity. Yet, it also defines an interior with both the enclosed spaces it constructs and the clear boundaries it creates with the exterior world in terms of the social and political differences it serves to underline. The protest camp emerges in contrast to an existing social order it wishes to abandon, at least within its own territory. ${ }^{5}$ Therefore, the political encampment is an architectural phenomenon combining the event and the site. ${ }^{6}$ Its erection is a political event on its own; hence, its physical existence is a political statement. And yet, it also serves as a site that embodies the real possibility of creating an alternative social order.

Although there have been singular cases of protest camps linked to particular issues in recent history, a significant wave of protest camps was the series of peace camps in the 1980s. A product of the Cold War, the peace camps were usually located outside military bases calling for the disarmament or the dismantling of the bases. In the following decade, camps raising ecological issues were established within the same framework. While the earliest examples of this protest trajectory were the anti-road camps in Britain, there were also those protesting against nuclear waste sites. In the 2000s, the environmentalist struggles gained impetus via global networks and climate camps were established in the United Kingdom as well as in other places such as Russia and Iceland. The first decade of the twenty-first century witnessed new forms of social movements, which took up the protest camp as a major tool. These movements targeted the expansion of neo-liberalism through free-market and free-trade regulations across the globe. As the World Social Forum (WSF) organizations began to take place, the G8 summits became scenes operationalized for mass protests. The short-term protest camps in Seattle (1999), Prague (2000) and Genoa (2001) resulted in the relocation of the summits in rather smaller cities, such as Evian (2003), Gleneagles (2005) and Heiligendamm (2007). ${ }^{7}$ While anti-globalization protests evolved into an alternative globalization movement through the WSF organizations, the second half of the decade witnessed 'No border' camps, defending freedom of movement against measures taken to control human migration especially in Europe. Finally, the protests that spread worldwide following the recent uprisings in North Africa were characterized by the protest encampments built in major city squares, the most striking (and inspiring) one being that in Tahrir Square in Cairo.

This brief history reveals that the protest camp has gradually become a significant form of peaceful political action. In this regard, it is not possible to miss the global character of the protest camp. Being global here not only refers to the existence of such camps in different parts of the world simultaneously; the protest camp, as a particular spatial form, emerges where the issue at stake itself has a global character. ${ }^{8}$ Beginning with the anti-war camps of the 1980s, the protest camps emerged as nodes of an international network of resistance. More correctly, where there has been an issue of protest that had an international character, the protestors chose to deploy the protest camp as an instrument. A major reason for this was simply the fact that an international/global question leads to the assembly of an international group of activists. When there are people moving across borders to protest, the question 
of accommodation emerges as an obvious practical concern. However, there is more to the global character of the protest camp. Significantly, an agenda effective beyond a particular locality transforms even the local protestors into outsiders; it distances them from their localities even if they physically remain in customary surroundings. They become part of a global network and detach themselves from their everyday lives. Hence, they turn into nomads, similar to their foreign compatriots arriving from different countries.

The experience of the camp then is inherently nomadic; it presents a condition of 'collective homelessness', which requires a certain level of detachment from home. ${ }^{9}$ In this respect, the protest camps of the twentyfirst century clearly share the common ground of being nomadic sites within the integrated globe of neo-liberalism. This integration links all issues of protest to each other, either through shared consequences (climate change), shared threats (control of migration) or simply a shared enemy (transnational capital). Here, before further dwelling on the nomadic struggle generated by the protest camp through the case of the TEKEL encampment, I shall provide a brief discussion on the background of TEKEL resistance.

\section{Background: Neo-liberalization in Turkey}

Since the 1980s, scholars have analysed various aspects of economic neo-liberalization and its social and political effects. Although its extensive use has made it harder to present a clear definition of the term, neo-liberalism is generally characterized by privatization of state enterprises, market deregulations, cuts in welfare expenditures, flexible labour market laws and the financialization of capital. ${ }^{10}$ Yet, as Neil Brenner and Nik Theodore have pointed out, although neo-liberalism implicates a transnational mobility, it assumes different social and institutional forms in different contexts. ${ }^{11}$ Hence, it is necessary to detail the particular forms of neo-liberal restructuring in Turkey, which is very much related to the emergence of TEKEL resistance. A major aspect of the neo-liberal programme implemented in the 1980s was the privatization of state enterprises across various sectors. These enterprises produced a major portion of the gross national product in the fields of energy and mining and formed approximately 30 per cent of the overall industrial production. ${ }^{12}$ The privatization of these enterprises proliferated in the following decades and required powerful governments since they met with working-class resistance. Nevertheless, the pace of privatization gradually increased and reached its peak after 2002 under the AKP. ${ }^{13}$ Similar to other cases of neo-liberal restructuring, the wave of privatization was coupled with a significant decrease in the level of wages and unionization and an increase in working hours due to flexible employment mechanisms. ${ }^{14}$ Thus, the level of unionized workers fell to 57.5 per cent by 2009. The rate of unionization, moreover, was 5.9 per cent in late 2011 (which was 10 per cent in 2001), the lowest among OECD members. ${ }^{15}$ The number of workers included in collective agreements fell from 786,000 to 365,000 between 1990 and 2009. ${ }^{16}$

Within this context, TEKEL was a major enterprise that went through all of the above-mentioned processes. The company lost an important portion of its market ratio due to the lifting of monopolies on cigarette production in 1986. In 2001, the export of tobacco was permitted and the prices were left to market determination. In the same year, 24 TEKEL plants were closed down. The company was divided into parts with the intent that they would be privatized separately in 2003. With the ultimate privatization of these components, 
the involvement of the state in the production and sale of tobacco and alcoholic beverages came to an end in 2008. ${ }^{17}$ While TEKEL had 30,124 workers in 2001, the number fell to 12,000 in 2008. Most of the workers who had been employed in the privatized sections were laid off. ${ }^{18}$ For the remaining workers, the government began working on a temporary employment status, which would lead to the TEKEL resistance in Ankara. ${ }^{19}$ Meanwhile, the TEKEL workers organized anti-privatization protests. In 2001, workers from various provinces met in Istanbul and protested against the laying off of around 4,000 TEKEL workers. Similarly, in 2003, they protested against the new labour regulations and the general policy of privatization. In 2006-08 workers protested against the closing of various sections and factories in different provinces. Finally, with the announcement of the closing down of TEKEL in December 2009, the 10,000 remaining workers were given the single option to give up their existing benefits and apply for the temporary employment status. Their response was to demand a re-employment plan in other state enterprises that would include their existing conditions of contract.

\section{The Site and the Rise of the TEKEL Encampment}

The TEKEL encampment took place in Ankara's Kizılay District. This district, which is today's city centre, was originally built as an upper-class neighbourhood intended to develop around the new Government Quarter. At the centre of the district sat Kizılay Square, an open space with two parks facing each other along Atatürk Boulevard, the main axis of the city running in a north-south direction. ${ }^{20}$ Kizilay Square was envisaged as the stage for a modern lifestyle by the republican elite. Yet, with the city's rapid growth in the post-war era, it gradually became a public space shared by diverse social actors. Moreover, it became the locale that would house student protests in 1960, making it the primary political space in the city. ${ }^{21}$ From then on, Kızılay Square would be the major locale for mass meetings in Ankara. Yet, within the context of the Cold War, Turkey witnessed the rise of political violence that suppressed such movements. While the 1970s witnessed bloody clashes, the military intervention in 1980 suppressed all kinds of political activities, closing down parties and organizations as well as the National Assembly.

The rise of political violence repressing grassroots movements went hand in hand with the destruction of public spaces in major cities. Kızılay Square, within this context, gradually turned into a traffic junction. Due to increasing traffic and the widening of the vehicular traffic lane, the parks and the promenade along Atatürk Boulevard were gradually squeezed out. Meanwhile, frequent commercial and leisure activities that formerly took place in the square had already expanded into the secondary streets around the square. With the expansion of the city centre, an additional belt developed along İzmir, Kumrular, Yüksel and Sakarya Streets, and parts of these streets were pedestrianized in time [Figure 2]. Pedestrianization began with Sakarya Street and its surroundings in 1978 and was followed by İzmir and Yüksel Streets in the 1980s. Although these sub-spaces around the square were connected via pedestrian overpasses, the increasing vehicular traffic and the expulsion of the pedestrians from the square resulted in the separation and functional specialization of these districts. ${ }^{22}$ While Kumrular Street functioned as an extension of the Government Quarter, İzmir Street worked as a shopping axis connecting apartment buildings with passages on ground floors specializing in garments. Yüksel District housed a number of civil organizations as well 


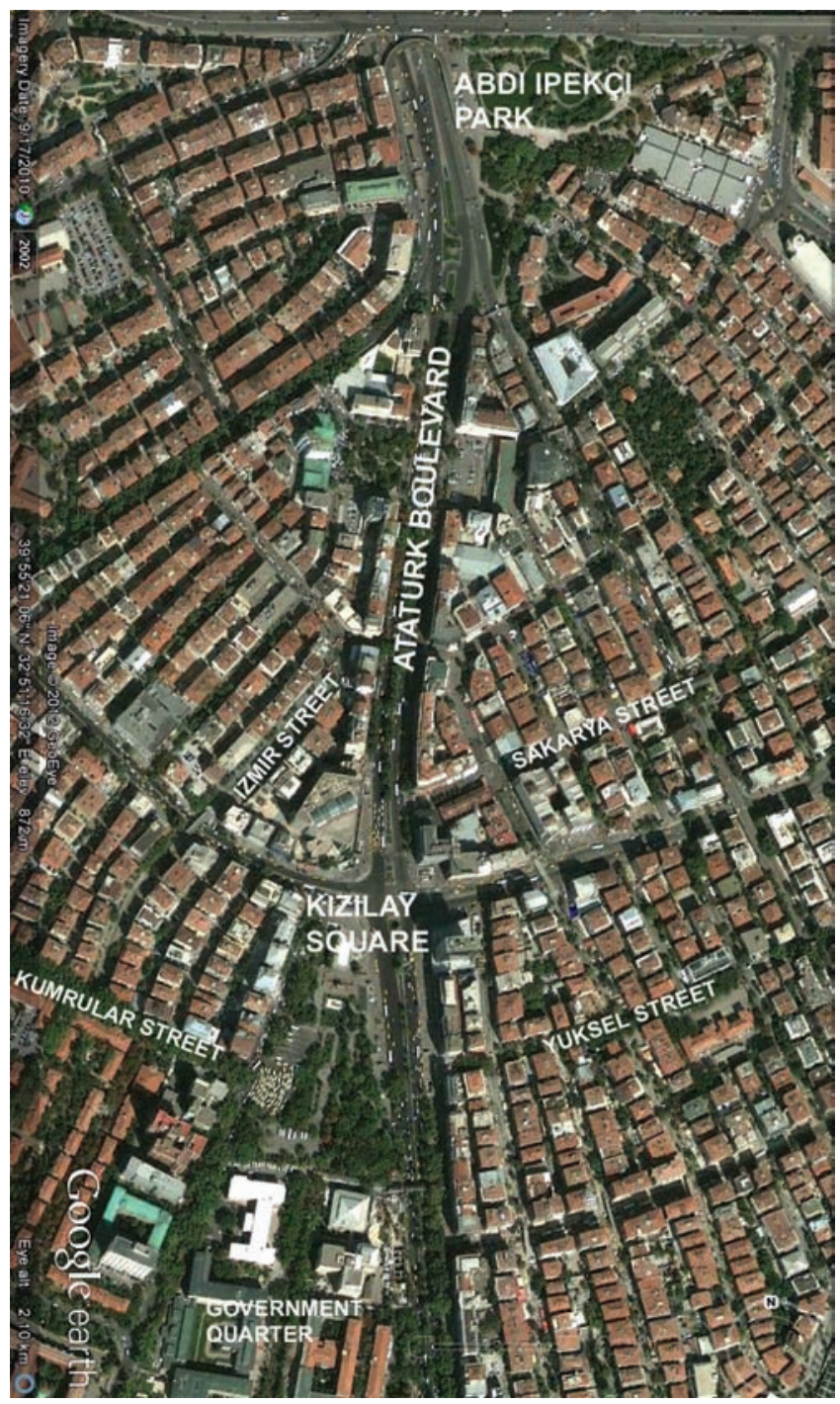

Google Earth.

Figure 2: Satellite image showing the Kizllay area.

as bookstores and private educational facilities, which turned it into a locale preferred by the youth. Sakarya District, in this spatial specialization, assumed the role of a gastronomical quarter mainly known for its bars.

The decline of Kizllay Square as an open space and the disruption of the continuous character of the centre turned these sub-spaces into secluded locales with specific functions. In the meantime, the historical role of the square as the public space of the city also deteriorated. Political demonstrations were banned in the square with the claim that such events created security threats due to the square's proximity to the National Assembly; yet, it was frequently used for non-political gatherings such as concerts and celebrations of sports events. Nevertheless, the square was occupied for mass meetings 
at times especially during the 1990s, when the governments were weak and the hegemony of the political establishment was under pressure from the Kurdish and Islamist oppositions. In the 2000s, however, the gradual institution of the AKP's hegemonic power was mirrored in the strict exercise of the ban on demonstrations in Kizllay Square. ${ }^{23}$ This was a clear attempt to eradicate the political connotations of the square in collective memory and an illustration of a new conception of urban public space that excluded politics. Here, public space came to be understood as a space of gathering controlled by authorities. Accordingly, Kizllay Square has often been a stage for events linked to traditional cultural practices in tune with the conservative stance of the government. Nevertheless, urban life is surprisingly capable of creating its own spaces of resistance. Beginning with the 1990s, Yüksel Street assumed the role of a political site for protest in the city centre due in part to its peculiar demographics bringing together civil organizations and the youth. Especially with the erection of the Human Rights Monument in the street in 1990, the area turned into the site of frequent political demonstrations. ${ }^{24}$

Within this context, it is even more unexpected to see the Sakarya area, one of the bar districts of the city, becoming the site of a major protest, and one that further assumed an unanticipated form - that of the protest encampment. As mentioned above, this was a spontaneous consequence of the events that took place in the few days following the arrival of the TEKEL workers in Ankara. The workers who arrived on December 15, 2009 met with a series of obstacles and, after lengthy negotiations with the governors' office, they were taken to a sports centre to spend the night. The next day, they were directed to Abdi İpekçi Park downtown, while some groups managed to return to the AKP headquarters. The workers refused to leave their places since they did not receive any attention from the government and most of them spent the second night out in the open. Finally, on December 17, the workers were dispersed brutally by the police with excessive use of tear gas. Some of the workers were thrown into the pool in the park, while some of them voluntarily jumped in to avoid the debilitating effects of tear gas. While opposition parties and civil organizations circulated statements protesting against the excessive violence exercised by the police, workers began to gather at the Türk-İş headquarters. The following days witnessed small protests by the workers in and around the union building while union leaders attempted to meet with government officials. Meanwhile, the number of workers grew with small groups arriving in Ankara evading police control at the city gates and ordinary people also began to visit in order to express solidarity. Finally, on December 23, the union declared that the workers would stay in Ankara and continue their resistance until an agreement was reached. ${ }^{25}$

Following the union's announcement calling for continuous action, the workers began to group together with respect to their union branches, which organized locally in terms of provinces. Each branch established its own tent, first with their own resources and then with contributions collected from various organizations. Therefore, the tents were the actual spaces representing the branches of the union; in a sense, the national organization of the union was reconstituted in physical form within the actual boundaries of the district, with the union headquarters as a focal point. The encampment became a spatial representation of the union as a body; the tents were the cells of this body, albeit reorganized in a different spatial order. The actual distances between provinces were now collapsed within the compressed space of the encampment. The implosion of distance had crucial outcomes since it forced the geographical differences inscribed in provincial identities to confront each other within the same space. 
The most significant of these differences was the ethnic identities that are encoded within the names of the provinces. People from the Black Sea region are automatically assumed to be conservative individuals with high nationalist sentiments whereas those from the Kurdish provinces are implicitly associated with the separatist PKK (Kurdistan Workers' Party). This confrontation was openly vocalized by the workers throughout the interviews made with them. ${ }^{26}$ Since the Kurdish question is one of the most critical items in the nation's political agenda, all of the workers faced their 'challengers' in the encampment. In this regard, although the encampment brought together people with shared interests, it also served as the site of contestation for conflicting (ethnic) identities. All of the interviewed workers declared that their views with regard to the 'others' had changed through the experience of the encampment. The shared experience eroded the workers' local identities and forced them to assume a cosmopolitan identity; they became nomads unlinked to particular social contexts. Slogans emphasizing 'the brotherhood of Turkish and Kurdish workers' and claiming that the Kurdish problem was 'truly solved in the encampment' were frequently cited by the workers in the interviews:

We often visit the other tents. Last night we were in the Diyarbakır tent. You know, Diyarbakır is always associated with terrorists on TV. But they joined our resistance. When I was still in Tokat, I was sceptical. But we got to know each other. We came together, sat, conversed, had fun together and realized that we are all the same. ${ }^{27}$

You know, our Prime Minister talks about [Kurdish] opening; we have already created the opening here. Those from the East, the West, the South and the North; the Laz, the Circassian, the Kurd and the Turk have blended here. We share our dinner plates. We sit in the tents together and chat. ${ }^{28}$

The same shift in perception was also valid for gender identities. The men and women sometimes had to literally share the collective beds inside the tents in the encampment. This was a huge transformation for both of the sexes; most of the workers, both male and female were coming from conservative backgrounds with strictly defined gender roles and limited socialization with the opposite sex. Yet, although they took on the gender roles expected of them (women mostly doing the cooking and the cleaning) in the beginning, soon they began to collaborate in the daily tasks and to interact with each other:

This has been a different experience for me; I have changed [...] I learned to express myself here. Before, I couldn't express my ideas as a woman, because I hadn't had the opportunity. Our branch in Bitlis [...] I mean it is a small province; it is not big like Ankara. Here I have observed that the women also have the right to be as free as the men. [This place] gives you the sense that the woman can be in everything, that her voice can be heard, that she has the chance to express her feelings and ideas, and herself. ${ }^{29}$

You know, normally, when a man and a woman come together, people would begin gossiping. Here, we never experienced gender discrimination. We chat freely with the opposite sex, and vice versa [...] We can talk to our male friends and share our problems. There is no gossip. ${ }^{30}$

The social experience inside the political encampment is determined by two major elements: the internal governance of the camp and the learning process 
that takes place within it. ${ }^{31}$ The internal organization in the TEKEL encampment rested on the actual organization of the union. Although this structure gave the union officials certain powers, a number of factors ultimately reduced their control over the encampment. The first of these factors was the fact that both the union and the Türk-İs confederation were reluctant to extend the duration of the protests and eager to negotiate with the government. ${ }^{32}$ The uncompromising attitude of the government forced the union officials to give in to the bottom-up pressure of the workers and this also significantly reduced their initiative in directing the resistance. ${ }^{33}$ Within this context, the tents became 'open spaces' where the workers discussed issues, made decisions and co-educated themselves. ${ }^{34}$ In addition to the internal tension within the union organization, the encampment as a particular social environment also supported horizontal decision-making processes. Moreover, the daily life in the camp was collectively organized and was in a sense inherently 'socialist'. ${ }^{35}$ Finally, the spatial characteristics of the encampment allowed for only limited control over boundaries - to which point I will return below. As a result, political parties and other organizations also built tents within the encampment, which would normally have been seen as an intervention that disturbed the union's authority.

With the reduced control of the union on the governance of the encampment, the workers felt free to speak individually (to the media) as representatives of the resistance. ${ }^{36}$ This, in return, increased each individual's involvement in different kinds of interactions with fellow workers, union leaders, political activists, etc. The intensification of interactions allowed the enrichment of experiences and the transformation of the campers' consciousness. The personal transformation of the protest campers is a topic that has been discussed to a certain extent. ${ }^{37}$ However, the political encampment also provided an opportunity to learn and to change, which is the second element that shaped the social experience within the camp. As illustrated with the above-quoted comments of the workers, their ideas regarding various subjects radically transformed through their experience in the encampment.

\section{Encampment as Public Space}

City squares function as important public spaces in different cities with distinct cultural and political contexts. They serve as open spaces in which everyday activities juxtapose with political events. Moreover, this juxtaposition allows for the politicization of the otherwise mundane practices, turning the city dwellers into political subjects even if they are not always directly involved in political actions. Arendt has famously defined public space as the 'space of appearance', where 'I appear to others as others appear to me, where men [sic] exist not merely like other living or inanimate things but make their appearance explicitly'.$^{38}$ Moreover, she reminds us of two significant aspects of public space: that 'it does not always exist' and that people cannot 'live in it all the time'. What we can derive from these propositions in terms of the spatiality of public space is that public space is not an ahistorical element that has a life of its own but a social construct that requires social relations to produce it. And with the caution that our existence in public space is always temporary - that is, our everyday lives cannot be consumed within public space - it becomes clear that the public space needs to be socially reproduced through our repetitive spatial practices. As Henri Lefebvre emphasizes with the concept of rhythmanalysis, everyday life has a multi-layered character, which is a result of the overlapping repetitive cycles that occur in urban 
space. ${ }^{39}$ The same is valid for political events: it is the repetition of such activities in certain spaces that makes them public spaces in collective memory. Urban space, for Lefebvre, is like 'flaky mille-feuille pastry' in which practices and meanings 'interpenetrate one another and/or superimpose themselves upon one another' ${ }^{40}$ Therefore, the analysis of public space requires the examination of 'layers' of everyday activities and their spatial formation along with the explicitly political practices performed therein.

If we return to the TEKEL encampment in the light of this dual focus, two dimensions should be addressed in analysing the Sakarya District. The first is the architectural vocabulary of the area as a pedestrian zone, which is compatible with the spatial character of the encampment. The second is the relation of the area to Kizllay Square at the edge of the centre. As opposed to the square as an open space, the pedestrian zone is a series of open and semiopen spaces, which is significant not only in terms of the spatial practices they generate but also the quality of being a 'space of appearance'.

An analysis of the spatial character of the area would show that, the Sakarya pedestrian zone is composed of five intersecting streets: Sakarya and Tuna Streets running in an east-west direction and Selanik, I-nkılap and Bayındır Streets running north-south [Figure 3]. The buildings along the streets are generally five to six storeys high, with the exception of the fourteenth-floor Social Security Organization (Sosyal Sigortalar Kurumu, SSK) building. This building was an important locale, housing shops, offices and even bars; nevertheless, it was undergoing renovation and was thus vacant during the TEKEL resistance. Following the pedestrianization of the area in the late 1970s, the

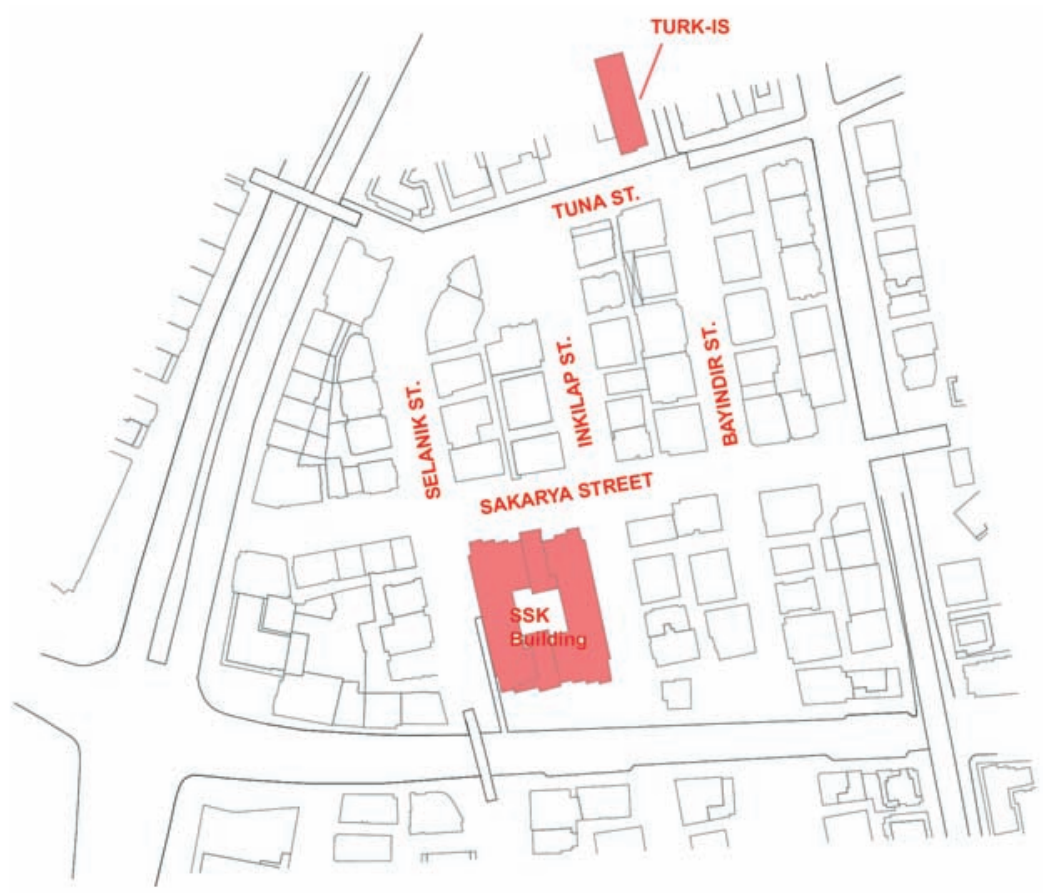

Meltem Al et al., 'Kentsel Odaklar', in Ankara Kent Atlası, ed. Güven Arif Sargn (Ankara: Mimarlar Odası Ankara Şubesi, 2012).

Figure 3: Map of Sakarya District. 
streets gradually transformed and adapted to the requirements of daily uses, sometimes through designed interventions but mostly by individual initiatives of the property owners. The street furniture (benches, steps, low walls, sculpture pedestals, portable umbrellas, canopies and sunshades) in the area allows for the occupation of space for eating and sitting through the afternoon and until late in the evening. ${ }^{41}$ Moreover, the area includes semi-permanent structures such as flower kiosks and newspaper stands, which further diminish the scale of open spaces in certain parts. As a result, the open spaces in the district range from 5 metres to 25 metres in width. Within this spatial context, the tents did not disturb the ongoing outdoor activities (which were already reduced due to the winter conditions) but on the contrary created new niches as well as new users.

The tents were erected along Tuna Street, on which the Türk-İş headquarters is located, as well as on the intersecting İnk1lap and Bayındır streets. They blocked the ground floors of the buildings, most of which were occupied by bars and restaurants. Interestingly, the owners and the staff of the bars supported the TEKEL workers and provided logistical assistance such as sanitary supplies and the use of the rest rooms of the bars. When the governor's office demanded the evacuation of the streets claiming they were harming the businesses, the bar owners erected banners declaring their support to the protestors.

The tents also differed in quality. The earliest ones were built of cardboard, plastic and canvas, using lamp posts and umbrellas as support [Figure 4]. Later on, ready-made tents were also erected by supporting organizations. The interiors of the tents were furnished flexibly for the mixed-use requirements of day and night. While they were used as gathering spaces for collective debates, they were treated by (especially female) workers as living rooms of their homes that had to be kept tidy for visitors [Figure 5]. At night, the floors were fully used for sleeping. On the other hand, there were also semi-open tents, which were closed on one side and provided a roofed extension to the street

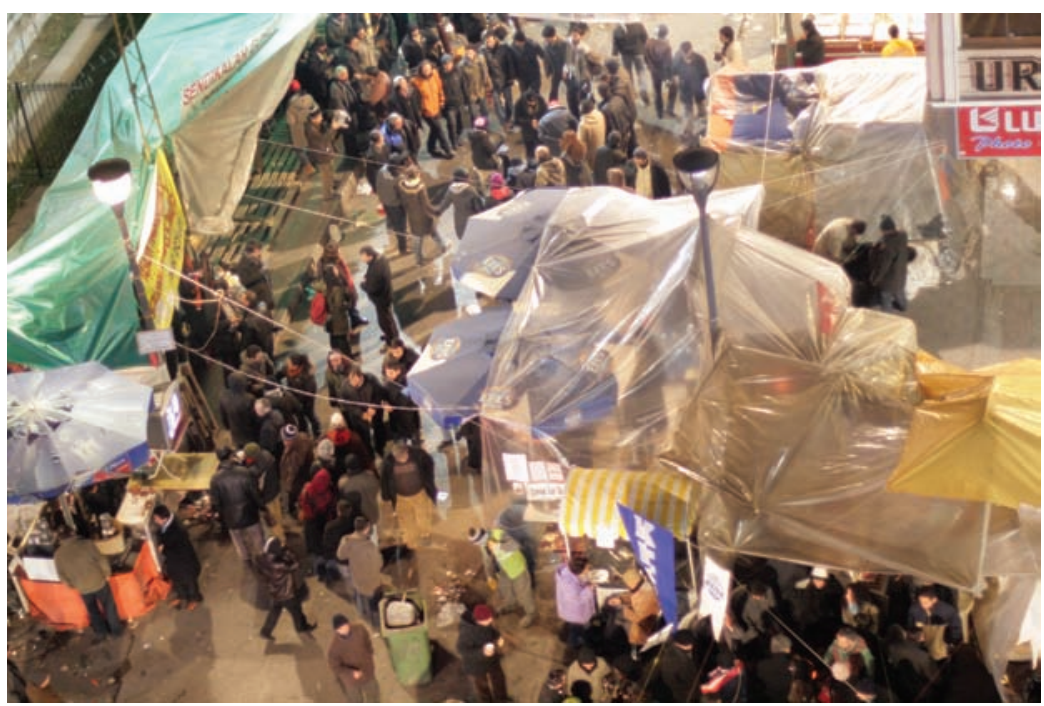

Mehmet Özer.

Figure 4: The architecture of the tents making use of street furniture. 


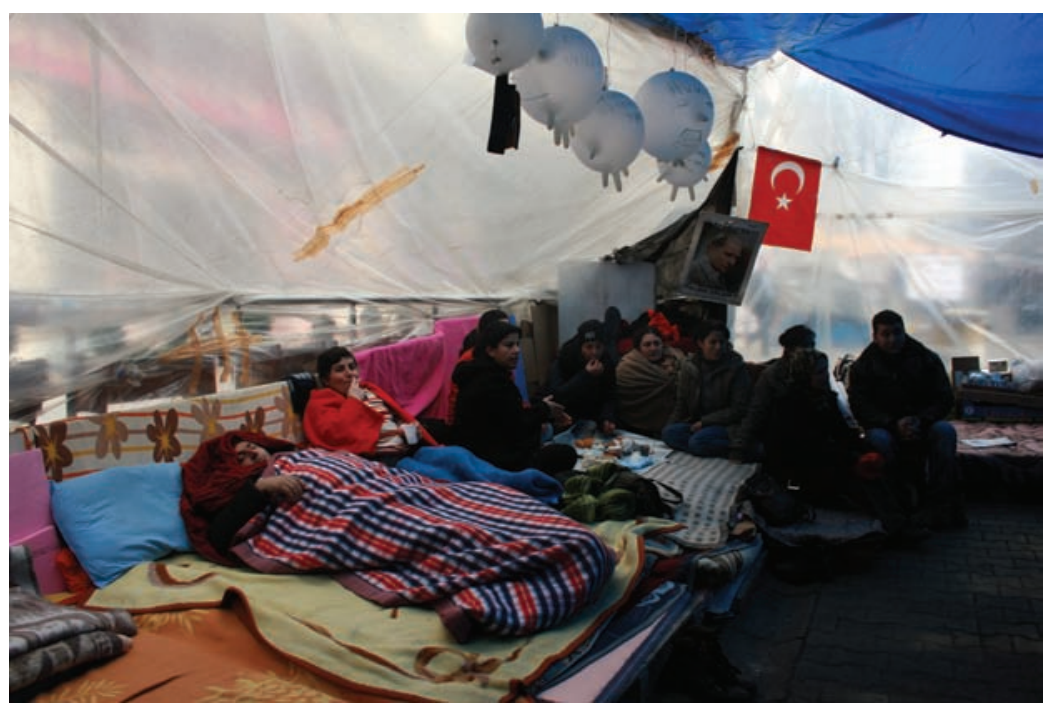

Mehmet Özer.

Figure 5: The interior of a tent.

[Figure 6]. Fireplaces were located frequently inside and outside, which served as foci around which people gathered in the cold weather. The varying size and shape of camp spaces allowed for distinct uses emerging in different locations. The workers used some spaces (especially the entrance of the Türk-Isş building) for small protests that took place when some news arrived regarding negotiations [Figure 7]. Larger areas such as intersections of streets were used to dance, since folk dances are a common scene in political demonstrations in addition to their role as material signifiers of local (provincial) identities.

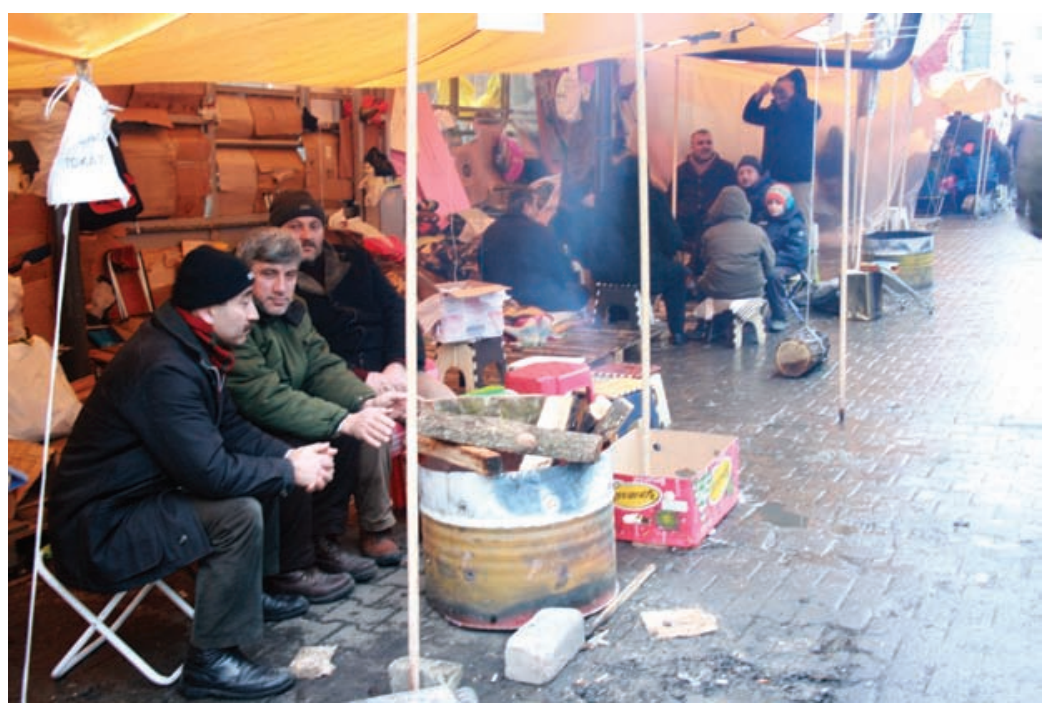

Mehmet Özer.

Figure 6: Semi-open spaces of the encampment along the street. 


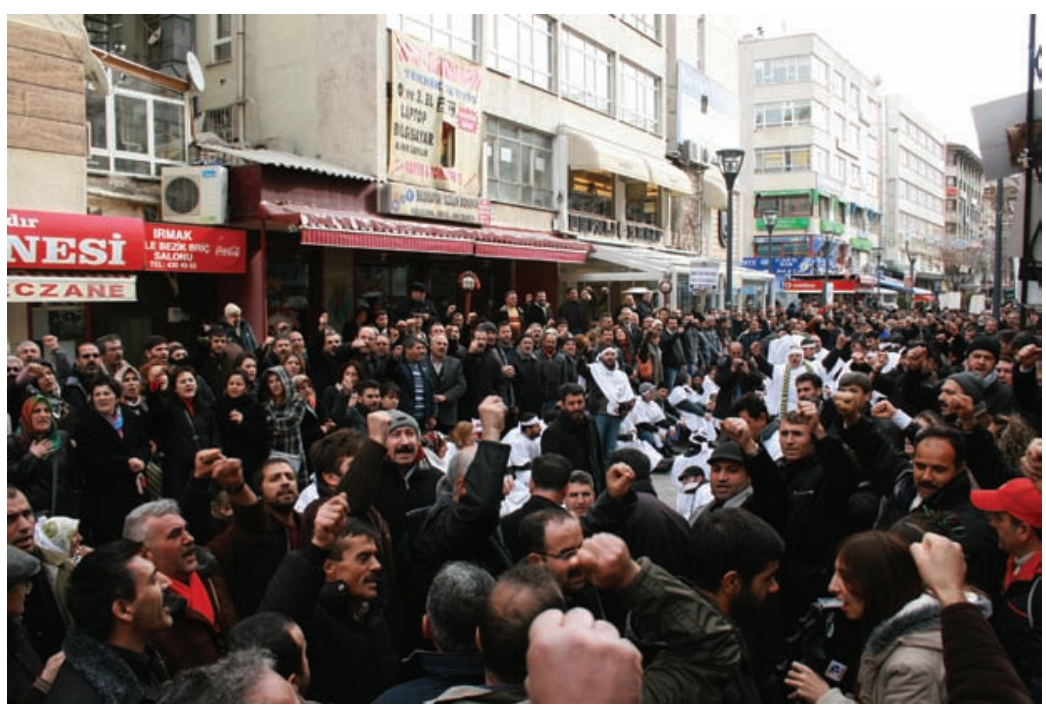

Mehmet Özer.

Figure 7: A small demonstration in Bayındır Street.

Lastly, the largest open space in the district - the segment of Sakarya Street in front of the SSK building - was the site of a spectacular mass rally on February 20, 2011, which lasted until the next morning.

Finally, it is necessary to examine the encampment in its relation to Kizılay Square, the open space that is perceived to be the actual political heart of the city. This examination can also provide a comparison with the protest encampments of 2011. As I have discussed earlier, the occupation of major city squares for longer time periods require a weakened hegemony and a strong popular support legitimizing the protests as in the cases of Tahrir and Puerte del Sol. In places where these conditions do not exist, even if the camps are built, protesters have to negotiate their existence with the authorities and abide by the daily routines such as traffic flow (as in the two 2011 cases of Zuccoti Park in New York and Rothschild Boulevard in Tel Aviv). In this respect, the political situation in Turkey definitely did not provide suitable conditions for such an encampment to be built in Kizllay Square. ${ }^{42}$

In the case of a conventional protest encampment, the campers settle in an open space and create an interior. The distinction between the interior and the exterior is established through internal regulations and shared practices rather than by means of physical borders. That is, the campers and the outsiders can be easily differentiated. The encampment, here, emerges as a means to sustain the protestors' appearance in the public sphere: an architectural object rising in the larger open space. From this point of view, the TEKEL encampment operates in a strikingly different way. If we remember that the Sakarya District was a component of the secondary belt surrounding the square, the visibility of the encampment as a political event significantly decreased here. In a sense, the political activity retreated into a secluded niche at the edge of the centre. Therefore, the TEKEL encampment did not stand as an architectural object representing its political statement through occupying the space of appearance. Instead it was located in a place where it was less visible 


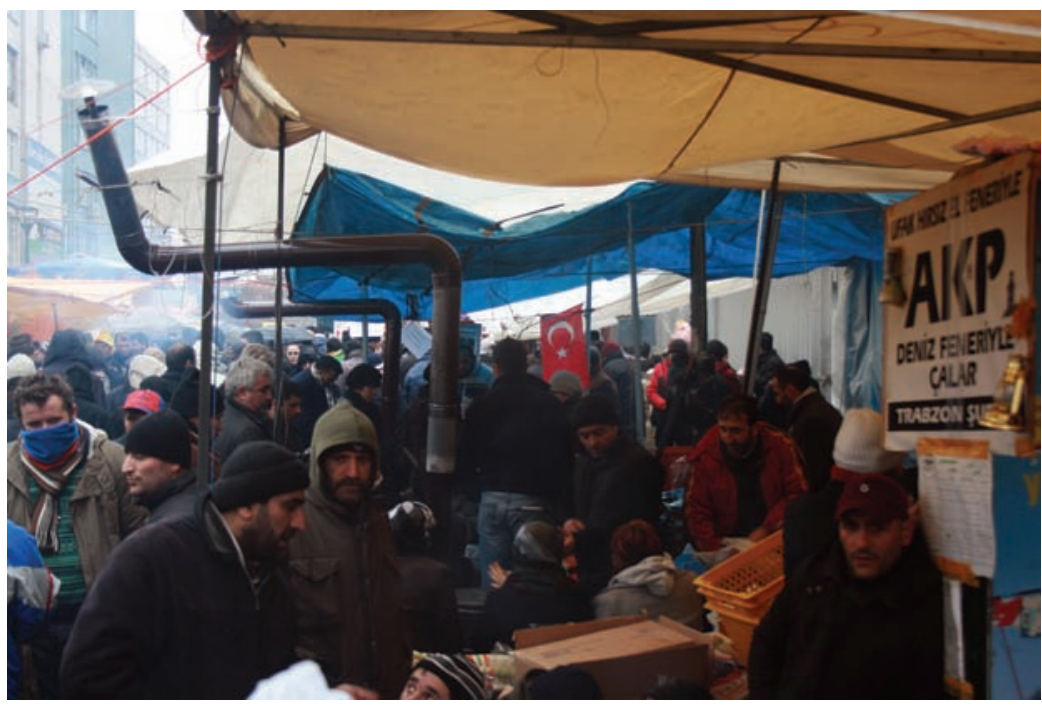

Mehmet Özer.

Figure 8: Ordinary users of Sakarya merging with the workers.

(publicly) and therefore transformed the existing urban texture by becoming part of the daily fabric.

The TEKEL encampment was a permeable structure with blurred boundaries since the practices inside the camp frequently expanded outside and spread into the whole district. In this regard, the involvement of the ordinary citizens was also encouraged by the spatial permeability of the encampment. A significant number of people visited the encampment and brought food, drinks and daily supplies to the protestors. They sat and chatted with the workers, who served them tea in return (a very common gesture of hospitality). Even people who were not related to the protest walked across the camp and along the streets that had been transformed into spaces of encampment [Figure 8]. This meant there was a constant interaction between everyday life in the Sakarya District and the political protest that emerged within it. Hence, in architectural terms, it is more appropriate to say that the encampment was not built in a detached form but rather that the streets were themselves transformed into an encampment. In this regard, the political encampment served as the material reconstruction of public space through the nomadic architecture of the workers.

This nomadic architecture appropriates urban space and radicalizes the notion of the protest camp as an antagonism to the existing order by transforming the daily routines of the ordinary users of the district. ${ }^{43}$ That is, rather than creating a temporary utopian social space for a limited group of activists, it operates as an architectural intervention changing the experience of the ordinary people in urban space. This is also in tune with the fact that the actual population of the encampment was comprised of workers who were linked to the local inhabitants of Sakarya in terms of political consciousness rather than activists with distinct agendas. Here, it is useful to recall Lefebvre's notions of 'experimental' versus 'abstract' utopia. For Lefebvre, abstract utopia 'attends to the ideal city without connection to definite situations', while experimental utopia explores 'imaginary variations on themes and exigencies defined by the 
real as understood in the broadest sense: by the problems posed by reality and by the virtualities held within it'. ${ }^{44}$ Accordingly, the TEKEL encampment can be considered an experimental utopia in comparison to the abstract utopias of common protest camps. Incidentally, as Tom McDonough has argued, Lefebvre's discussion of experimental utopia resonates with the situationist architect Constant Nieuwenhuis's 'Project for a Gypsy Camp', which used the nomadic life of the gypsies as a model for a utopian future: 'We are becoming nomads once more, wandering over the earth, not looking for rest but for dynamic motion. ${ }^{45}$ If it is true that the political encampment is an architectural form of nomadic existence within the neo-liberal milieu, we should also explore its relationship to the concept of home, the essential form of dwelling in the world.

\section{Nomadic Architecture: Encampment versus Home}

The architecture of the TEKEL encampment requires evaluation in relation to the contemporary urban conditions of the Turkish working class. A major element characterizing Turkish neo-liberalization was the gradually increasing role played by urban space as a means for capital accumulation. Beginning with the 1980s, both the local government structures and the methods of urban space production gained new forms, turning cities into major sites of accumulation. ${ }^{46}$ This trend also reached an unprecedented scale under the AKP. In 2004, urban regeneration became a legal term in Turkey. After that, with a series of legislative changes, the TOKİ and local municipal administrations were granted powers to renew old squatter areas and the historic centres of the cities. ${ }^{47}$ The extensive powers vested in these agents resulted in the maximization of profit and the lack of public participation in decisionmaking processes. Squatters are now left with the choice to either move out of the designated regeneration zones or use the expropriation money as a down payment and take TOKİ loans to acquire a new apartment in the same area.

What must be added to these observations is the radical disjuncture between the stereotypical architecture of the high-rise apartment blocks mandated for the working-class squatters and the single-storey shacks they formerly occupied. These shacks, albeit often unsanitary, were yet compatible with their social and spatial practices. In this regard, the TOKI blocks emerge as the antithesis of the squatter homes [Figure 9]. While the latter was the self-help environment of the migrants that spontaneously developed in tune with the social requirements of the users and the physical constraints of the environment, the former provided sanitation yet destroyed social and environmental consistency. In this regard, the forced detachment of the workers from their lives (literally) on the ground and their relocation within the standardized blocks of apartments should be understood as an architectural expression of the neo-liberalization process. While the employment status, job security and wage levels decline for workers in all sectors, their neighbourhoods are also destroyed and they are forced to live inside the alienating apartment blocks. ${ }^{48}$

Here, it is necessary to avoid essentializing the squatter home as an ideal architectural type. In addition to their variety in terms of social characteristics and physical qualities, squatter neighbourhoods in Turkish cities have undergone transformations across time. ${ }^{49}$ Nevertheless, it is possible to define the squatter home in general terms as a form of low-income, self-help housing, 


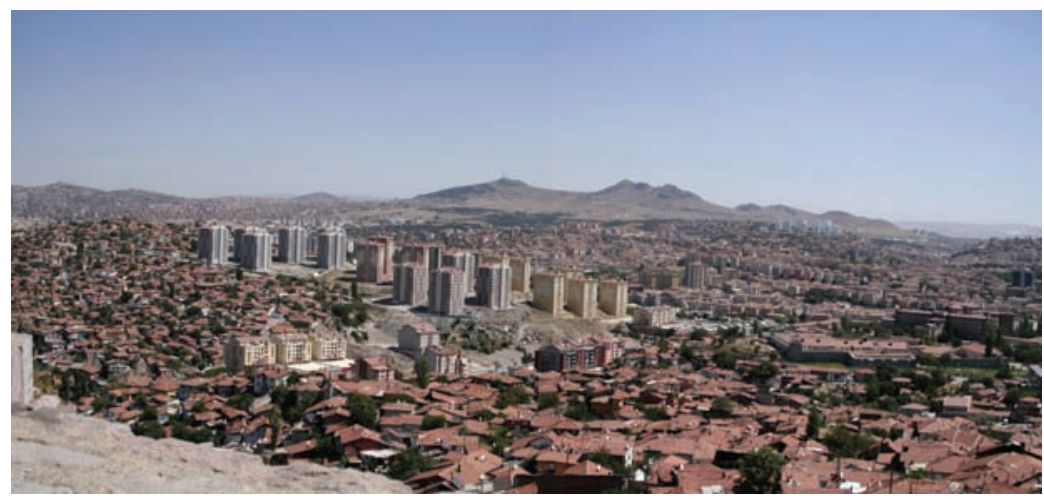

Chamber of Architects of Turkey, Ankara Branch Archive.

Figure 9: TOKI housing blocks erected in the middle of a traditional squatter neighbourhood in Ankara.

built collectively with traditional methods. The neighbourhoods created in this way inevitably end up in organic and irregular forms. Within this context, the encampment is a symbolic return to the squatter neighbourhood with narrow streets and courtyards. The camp, after all, is the sum of open spaces defined by tents with 'a protected back, an open front, a fireplace and a roof'. ${ }^{50}$ The squatter neighbourhood is characterized by the interpenetration of public and private zones; the immediate surroundings of the houses are used especially by the women as semi-private gathering spaces. Certain chores are done outside (such as washing carpets) and sometimes they are handled collectively by the neighbours. These kinds of activities are forbidden by written regulations in the TOKİ complexes. ${ }^{51}$ In this respect, the TEKEL encampment resembles a squatter neighbourhood not only physically but also socially. The creation of closed and semi-open spaces with blurred boundaries allows for the flexible use of spaces where certain activities easily move between the interior to the exterior. Therefore, the encampment was at the same time a significant architectural critique of the neo-liberal urbanism imposed on the workers in the form of TOKİ housing projects. Presented to the workers as healthy and modern living conditions, the sedentary life of the standardized apartment blocks was negated here, in favour of a nomadic existence reconstituting the workers as public beings in urban space.

\section{Conclusion}

The TEKEL resistance created an unexpected excitement among leftist intellectuals and activists. Nevertheless, the movement gradually lost its momentum due in large part to the reluctance of the union leaders to continue the struggle. ${ }^{52}$ The encampment was dismantled on March 2, 2010, with the explicit warning from the workers that they would return if their conditions were not improved. However, when the workers attempted to return to Sakarya in response to the government's adamant stance, they met with blockades at the city gates and more significantly around the entire Sakarya District. On April 1, the previously announced day of protest, the entrances to the pedestrian zone were blocked by the police early in the morning and there were again serious clashes around Kizılay throughout the day. Yet, since 
Sakarya District was a major pedestrian passageway, some 2,000 protestors managed to gather in Sakarya Street, although they were not allowed to reach the Türk-İş building. The spatial strategy of the police, who were determined to prevent the reconstruction of an encampment, concentrated on creating concentric zones of restriction. While they dispersed the protesting groups that gathered in various locations in Kizllay, they tried to blockade the district of Sakarya altogether. Moreover, the immediate perimeters of the Türk-İş building were further fortified with police barricades. In a sense, this was the inversion of the spatial configuration of the encampment that concentrated around the Türk-İs headquarters and spread into the pedestrian zone. This defensive strategy also confirmed the meaning of the district as a political zone.

In fact, Sakarya Street became the locale of various protests in the following months. The rallies could not be banned here since they did not obstruct traffic or threaten the Government Quarter (excuses used to ban political demonstrations in Kızılay Square). Therefore, Sakarya began to take over the role of Yüksel Street as the major locale of protests with its larger open space. A major lesson learned by both the protestors and the government was the power of the encampment as a spatial form. Especially with the global spread of protests and encampments, the government made sure that similar encampments were not erected elsewhere.

The examples of political encampments in different parts of the world provide architectural models of political activism each of which contains peculiarities worth analysing. Following Arendt, the protest camp can be regarded both as a type of public space of interaction and an architectural form to occupy public space in its temporary existence making politics visible. In addition, the TEKEL encampment illustrates that the protest camp can be utilized not only to occupy public space but also to (re)construct it within the urban fabric.

\section{Suggested Citation}

Batuman, B. (2013). 'Political Encampment and the Architecture of Public Space: TEKEL Resistance in Ankara', International Journal of Islamic Architecture 2: 1, pp. 77-100, doi: 10.1386/ijia.2.1.77_1

\section{Contributor Details}

Bülent Batuman received a master's degree in Architecture from the Middle East Technical University, followed by a Ph.D. in History and Theory of Art and Architecture from the State University of New York, Binghamton. He currently teaches courses on the history and theory of urban design in the Department of Urban Design and Landscape Architecture at Bilkent University in Ankara, Turkey. His research areas include the social production of the built environment; history and theory of modern architecture and urbanism; urban politics; and critical theory.

Contact: Bilkent University, Department of Urban Design and Landscape Architecture, 06800 Ankara, Turkey.

E-mail: bbatuman@yahoo.com

Bülent Batuman has asserted his right under the Copyright, Designs and Patents Act, 1988, to be identified as the author of this work in the format that was submitted to Intellect Ltd. 


\section{Endnotes}

1. The photographs of the TEKEL encampment I use throughout the article were taken by photographer Mehmet Özer. I thank him for giving permission to use his photographs.

2. Hannah Arendt, The Human Condition (Chicago: University of Chicago Press, 1998), 199.

3. Below, I will briefly discuss how I use the term 'neo-liberalism'.

4. Although I am only interested in the protest camps here, there is a growing literature on camps in general, focusing on various forms of camps ranging from touristic camps to military camps, concentration camps and refugee camps. See Charlie Hailey, Campsite: Architectures of Duration and Place (Baton Rouge: Louisiana State University Press, 2008); Charlie Hailey, Camps: A Guide to 21st-century Space (Cambridge, MA: The MIT Press, 2009); Gerald Allan Cohen, Why not Socialism (Princeton: Princeton University Press, 2009); Fabian Frenzel, 'Exit the System: Crafting the place of protest camps between antagonism and exception' (working paper, University of the West of England, 2011).

5. Frenzel, 'Exit the System'.

6. Hailey, Camps, 3.

7. Frenzel, 'Exit the System'.

8. It also has to be noted that the rise of the encampment as a form of protest is related to the contemporary conditions of increased mobility. See Kevin Hannam, Mimi Sheller and John Urry, 'Editorial: Mobilities, Immobilities and Moorings', Mobilities 1.1 (2006): 1-22.

9. William Mangold, 'Review: Camps: A Guide to 21st-Century Space; Campsite: Architectures of Duration and Place; and A Manufactured Wilderness: Summer Camps and the Shaping of American Youth, 18901960', Journal of Architectural Education 64.2 (2011): 178.

10. For the history of neo-liberalism, see Susan George, 'A Short History of Neoliberalism: Twenty Years of Elite Economics and Emerging Opportunities for Structural Change', in Global Finance: New Thinking on Regulating Capital Markets, ed. Walden Bello, Nicola Bullard and Kamal Malhotra (London: Zed Books, 2000); David Harvey, A Brief History of Neoliberalism (Oxford and New York: Oxford University Press, 2007). The term itself has now become the focus of a vast literature and it is also possible to come across different - and at times contradictory - uses of the same term. See James Ferguson, 'The Uses of Neoliberalism', Antipode 41.1 (2009): 166-84.

11. Neil Brenner and Nik Theodore, 'Cities and the Geographies of "Actually Existing Neoliberalism"', in Spaces of Neoliberalism: Urban Restructuring in 
North America and Western Europe, ed. Neil Brenner and Nik Theodore (Oxford: Blackwell, 2002), 2-32.

12. Nergis Mütevellioğlu, 'Özelleştirmelerin Krizine Karşı Toplumsal Olanı Savunmak', in TEKEL Direnişinin Işı̆̆ııda Gelenekselden Yeniye İş̧̧ Sinıfı Hareketi, ed. Gökhan Bulut (Ankara: Nota Bene, 2010), 152.

13. The value of enterprises privatized between 1986 and 2003 was 8 billion US dollars, while this number was 33 billion US dollars for the next seven years. This means that 80 per cent of the privatizations were realized in 2003-10. See Nuray Türkmen, Eylemden Öğrenmek: TEKEL Direnişi ve Sinıf Bilinci (Istanbul: İletişim, 2012), 31.

14. Between 1988 and 2008 production and productivity increased 185 per cent and 229 per cent respectively in Turkey, while employment decreased 13 per cent and wages 35 per cent. By 2008, 70 per cent of the workforce was working more than 40 hours per week. See Arzu Çerkezoğlu and Özay Göztepe, 'Sınıfını Arayan Siyasetten Siyasetini Arayan Sınıfa: Güvencesizler', in TEKEL Direnişinin Işı̆̆ııda, 2010, 78-80.

15. Aziz Çelik, 'OECD'nin En Sendikasızı Türkiye', Sendika.org, November 25, 2011, accessed on May 22, 2012, http://www.sendika.org/yazi.php?yazi_ no $=41172$.

16. Çerkezoğlu and Göztepe, 'Sınıfını Arayan Siyasetten Siyasetini Arayan Sinifa', 73. Although a detailed analysis of neo-liberalization in Turkey is beyond the scope of this article, it is crucial to note that this process was coupled by the rise of Islamist politics in the 1990s as a response to the rapid deprivation of the lower classes in the face of neo-liberal policies. See Cihan Tuğal, Passive Revolution: Absorbing the Islamic Challenge to Capitalism (Stanford, CA: Stanford University Press, 2009). In the 1990s, the Islamists gained control of local administrations and utilized them to implement welfare networks in collaboration with Islamic associations. See Jenny White, Islamist Mobilization in Turkey: A Study in Vernacular Politics (Seattle: University of Washington Press, 2002). With the AKP coming to power in 2002, these welfare networks were gradually incorporated into the state structure, which went hand in hand with an aggressive campaign of privatizations and the implementation of anti-labour regulations. Thanks to relatively advantageous conditions of the global economy directing foreign investments into the country, the AKP managed to balance these two strategies albeit coupled with a chronic current-account deficit.

17. Türkmen, Eylemden Öğrenmek, 32-39.

18. While British American Tobacco, which had bought the cigarette and tobacco sections of TEKEL laid off 8,247 of the 10,818 workers, the number of workers in the alcoholic beverages section bought by MEY A.Ş. dropped from 3,631 in 2003 to 323 in 2009. See Türkmen, Eylemden Öğrenmek, 37; Tülay Özerman, 'Tekel Özelleştirmesinin Sonuçları', Mülkiye 33.262 (2009): 293. 
19. The temporary employment status was defined in the Civil Servants Act and denied the workers the rights of organization, collective bargaining, employment security and even overtime payment.

20. For a study analysing the transformation of public life in Turkey through the spatial history of Kızılay Square, see Bülent Batuman, The Politics of Public Space: Domination and Appropriation in and of Kizllay Square (Saarbrücken: VDM Verlag, 2009).

21. Bülent Batuman, 'Imagination as Appropriation: Student Riots and the (Re)Claiming of Public Space', Space \& Culture 6.3 (2003): 261-75.

22. Özlem Ortaboy Eldemir, 'Reevaluating the Historical Spatial Structure of the Ankara Atatürk Boulevard as a Sequence of Urban Spaces and Plazas' (master's thesis, Middle East Technical University, 1991), 96-97.

23. The most recent example of the dispute over Kizllay Square was the school teachers' protest against the new education system. On March 28, 2012, protesting groups in three different locations around Kizllay attempted to unite at the square but met with a violent response from the security forces.

24. Tonguç Akış, 'Urban Space and Everyday Life: Walking through Yüksel Pedestrian District (YPD)' (master's thesis, Middle East Technical University, 2001).

25. The union's declaration did not specifically use the term 'resistance' but 'continuous action'. Nevertheless, the workers labelled the protest as 'resistance' and the action soon publically assumed the label of 'TEKEL Resistance'.

26. TEKEL resistance was extensively documented, which is also a sign of the attention it aroused. Social and political scientists as well as activist groups conducted research and amateur and prominent photographers visually documented the encampment. As a result, a number of publications and photography exhibitions came out in the following months after the encampment was taken down. The publications differed in content and style. Some were published by unions and political organizations. See Türk-İş, Mücadeleyle Geçen 78 Gün: TEKEL Eylem Günlüğ̈̈ (Ankara: Türk-İs, 2010); Kolektif, TEKEL Direnişi Dersleri 2010: Sendikalarmmızı Geri Alacağız! (Istanbul: Kaldıraç, 2010). There were also scholarly studies, some of which were collected works documenting findings of research conducted in the encampment. See Gökhan Bulut, ed., TEKEL Direnişinin Işı̆̆ında Gelenekselden Yeniye (Ankara: Nota Bene, 2010); Gamze Y1kılmaz and Seray Kumlu, eds., TEKEL Eylemine Kenar Notları (Ankara: Phoenix, 2011). Some of these studies developed into graduate theses. See Mehtap Tosun, 'Flexible Labor Policy and the Crisis of Trade Unionism: The Case of TEKEL Workers' Resistance in Ankara' (master's thesis, Middle East Technical University, 2011); Seray Kumlu, 'Neoliberal çağda İşçi Sınıfının Konumu ve Sınıf Hareketi: 4/C ve TEKEL Direnişi Örneği' (master's thesis, Ankara University, 2012); Eylem Tuna, 'Medyada İşçi Hareketleri ve Sendikacılık Bir Örnek: Tekel Eylemleri' (master's thesis, Marmara University, 2011). 
27. Quoted in Türkmen, Eylemden Öğrenmek, 131.

28. Quoted in Yikılmaz and Kumlu, TEKEL Eylemine Kenar Notları, 222.

29. Quoted in Türkmen, Eylemden Öğrenmek, 152.

30. Quoted in ibid., 153.

31. Frenzel, 'Exit the System'.

32. The reluctance of the union leaders to pursue the struggle and the failure of other unions in the Türk-İş confederation to support the movement created considerable discouragement for the workers. The tensions within the union and the adamant attitude of the government led the workers to put their hopes in the lawsuit against the notice period of 30 days to apply for the temporary employment status announced by the government. The Council of State ruling that cancelled the notice period was celebrated by the union as a victory and the encampment was dismantled afterwards. Although the workers declared that they would return to Sakarya on April 1 if there wasn't any improvement in their status, this attempt was blocked by the government and the resistance faded away with no real achievements.

33. For a discussion of the workers' relation to the union during the TEKEL resistance, see Elif Hacısalihoğlu, Göksu Uğurlu and Gamze Yücesan Özdemir, '21. Yüzyılda Sosyal Hak Mücadelesi: TEKEL Direnişi' (paper presented at the Second National Symposium on Social Rights, Pamukkale University, November 4-6, 2010).

34. Chloé Keraghel and Jai Sen, 'Explorations in Open Space: The World Social Forum and Cultures of Politics', International Social Science Journal 56.182 (2004): 483-93.

35. Cohen, Why not Socialism, 10.

36. Gökhan Bulut, 'Direnişin Bilinç ile İmtihanı', in TEKEL Direniş̧inin Işı̆̆ında Gelenekselden Yeniye, 124.

37. Véronique Rioufol, 'Approaches to Social Change in Social Forums: Snapshots of Recompositions in Progress', International Social Science Journal 56.182 (2004): 551-63.

38. Arendt, The Human Condition, 198-99.

39. Henri Lefebvre, Rhythmanalysis: Space, Time and Everyday Life, trans. Stuart Elden and Gerald Moore (London: Continuum, 2004).

40. Henri Lefebvre, The Production of Space, trans. Donald Nicholson-Smith (Oxford and Cambridge: Blackwell, 1991), 86.

41. See Shihibuddin Mahmud, 'Evaluation of Outdoor Activities in Downtown Areas Within the Context of Time and Provided Space: Case 
of Kızılay' (master's thesis, Bilkent University, 1996), 98-105 and Meltem Al, Aslıhan Günhan, Sıla Karataş and Erkut Sancar, 'Kentsel Odaklar', in Ankara Kent Atlası, ed. Güven A Sargın (Ankara: Mimarlar Odası Ankara Şubesi, 2012).

42. The government made sure that a similar encampment was not built again in Ankara. A year later, environmentalist groups protesting against new legislation that would allow the construction of hydroelectric plants on rivers attempted to meet in Ankara. As they were not allowed to enter the city, their attempt to build an encampment at the city gates was also obstructed.

43. Frenzel discusses the protest camp in relation to Agamben's notion of 'exception' claiming that the protest camps should aim to create 'an antagonism that does not become an exception', see Frenzel, 'Exit the System'.

44. Henri Lefebvre, 'Excerpts from "Experimental Utopia: Toward a New Urbanism"', in Situationists and the City, ed. Tom McDonough (London: Verso, 2009), 105.

45. Quoted in Tom McDonough, 'Metastructure: Experimental Utopia and Traumatic Memory in Constant's New Babylon', Grey Room 33 (Fall 2008): 90. Constant would develop his famous 'New Babylon' project along the same ideas and create an environment in which all humans become detached travellers who are 'displaced and only have each other to turn to. Contacts are made which, in normal circumstances, would be more difficult to establish.' See Mark Wigley, Constant's New Babylon: The Hyper-Architecture of Desire (Rotterdam: 010 Publishers, 1999), 200.

46. Bülent Batuman, 'City Profile: Ankara', Cities (2012), doi: 10.1016/j. cities.2012.05.016.

47. State institutions responsible for housing and land development were closed down and their duties and assets were handed over to TOKİ. Similarly, the duties of the Ministry of Public Works regarding slum clearance were also transferred to TOKİ. Becoming exempt from almost all of the bureaucratic mechanisms, TOKI became the major actor in housing production and the main facilitator of public-private partnerships. As a result, the number of houses built by TOKİ between 2003 and 2010 reached 500,000, while this number was merely 43,000 for the period 1984-2003. See TOKİ, Building Turkey of the Future: Corporate Profile 2010/2011 (Ankara: TOKİ, 2011).

48. There are recent studies analysing the problems experienced by the relocated squatters in the TOKI housing sites. For example, see Cihan Uzunçarşı1ı Baysal, 'Ayazma'dan Bezirganbahçe'ye: Yeniden İskanın Yarattığ1 Kültürel Mağduriyetler ve Yeni Kimlik İnşası', Dosya 16 (October 2009): 35-41; Tahire Erman, 'Kentsel Dönüşüm Projesi ile Dönüşen/ Dönüş(e)meyen Yaşamlar: Karacaören-TOKİ Sitesindeki Günlük Yaşam Pratikleri', Dosya 27 (December 2011): 25-31. 
49. Tansı Şenyapıll, Barakadan Gecekonduya: Ankara'da Kentsel Mekanın Dönüşümü: 1923-1960 (Istanbul: İletişim, 2004); Işık Aksulu and Olcay Aykut, 'Transformation of Traditional Architecture in Self Built Housing', Journal of Research in Architecture \& Planning 2 (2003): 81-98.

50. Hailey, Camps, 5.

51. Erman, 'Dönüşen/Dönüş(e)meyen Yaşamlar', 27.

52. For a detailed chronology of the TEKEL resistance, see Bulut ed., TEKEL Direnişinin Işı̆̆ııda, 301-52. 
Copyright of International Journal of Islamic Architecture is the property of Intellect Ltd. and its content may not be copied or emailed to multiple sites or posted to a listserv without the copyright holder's express written permission. However, users may print, download, or email articles for individual use. 